\title{
Going Green in Business-A Study on the Eco- friendly Initiatives towards Sustainable Development in India
}

\author{
Pradeep M. D. ${ }^{1}$, \& Akhilesh Suresh A Kuckian ${ }^{2}$ \\ ${ }^{1}$ Research Scholar, Alliance School of Law, Alliance University, Bengaluru \& Assistant \\ Professor, College of Social Sciences and Humanities, Srinivas University, Mangaluru, \\ Karnataka, India. \\ ${ }^{2}$ Lecturer, Department of Commerce and Management, Srinivas University, \\ Mangaluru, Karnataka, India \\ E-mail: mdpradeepnair767@gmail.com
}

Type of the Paper: Research Paper.

Type of Review: Peer Reviewed.

Indexed In: OpenAIRE.

DOI: http://dx.doi.org/10.5281/zenodo.1017596.

Google Scholar Citation: IJAEML

\section{How to Cite this Paper:}

Pradeep., M. D, \& Suresh A Kuckian, Akhilesh. (2017). Going Green in Business - A Study on the Eco-friendly Initiatives towards Sustainable Development in India. International Journal of Applied Engineering and Management Letters (IJAEML), 1(2), 40-50.

DOI: http://dx.doi.org/10.5281/zenodo.1017596.

International Journal of Applied Engineering and Management Letters (IJAEML) A Refereed International Journal of Srinivas University, India.

(C) With Authors.

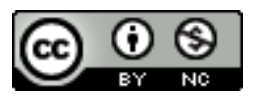

This work is licensed under a Creative Commons Attribution-Non Commercial 4.0 International License subject to proper citation to the publication source of the work.

Disclaimer: The scholarly papers as reviewed and published by the Srinivas Publications (S.P.), India are the views and opinions of their respective authors and are not the views or opinions of the S.P. The S.P. disclaims of any harm or loss caused due to the published content to any party. 


\title{
Going Green in Business - A Study on the Eco-friendly Initiatives towards Sustainable Development in India
}

\author{
Pradeep M. D. ${ }^{1}$, \& Akhilesh Suresh A Kuckian ${ }^{2}$ \\ ${ }^{1}$ Research Scholar, Alliance School of Law, Alliance University, Bengaluru \& Assistant \\ Professor, College of Social Sciences and Humanities, Srinivas University, Mangaluru, \\ Karnataka, India. \\ ${ }^{2}$ Lecturer, Department of Commerce and Management, Srinivas University, \\ Mangaluru, Karnataka, India \\ E-mail: mdpradeepnair767@gmail.com
}

\begin{abstract}
Increasing awareness on the various environmental problems has led to a shift in consumer behaviour. There has been a change in consumer attitude towards a green lifestyle. Thus green Marketing has evolved special implications in the modern market. Green indicates purity through quality, fairness in price and worthy in dealings. Green marketing focuses on marketing eco-friendly products to satisfy the needs and wants of the customers. It adopts innovative techniques of product modification, dynamic product process, maintaining sustainability and diversified advertising etc. The vision of Green marketing is to protect ecological environment. Present day customers need to be socially responsible and conscious towards environmental aspects. Green marketing is a phenomenon which has developed particular important in the modern market and has emerged as an important concept in India as in other parts of developing and developed world, and is seen as an important strategy of facilitating sustainable development. In this research paper, the main emphasis has been made of concept, need and importance of green marketing. Data had been collected from multiple sources of evidence, in addition to books, journals, websites, and newspapers. It explores the main issues in adoption of green marketing practices. The paper describes the current scenario of the Indian market and explores the challenges and opportunities businesses have with green marketing.
\end{abstract}

Keywords: Green Marketing, Opportunities, Environmental problems, Product modification.

\section{INTRODUCTION :}

In India, Green marketing is gaining importance within the modern market system. It helped companies in the process of co-branding the products into a new line of business known to be environment friendly goods and services. According to Polonsky J, Green marketing is an activity to meet emerging human wants and desires by minimising the detrimental effects caused over the environment due to such actions. Green marketing is also known as environmental marketing or ecological marketing. As the resources are depleting every second and human want is increasing every minute, it is very essential to reduce the wastage of resources to protect the environment. The Ecological issues are influencing business practices, as organisations started to perceive environmental issues to take up strategic changes, many establishments are adopting eco friendly marketing strategies to gain competitive advantage [1]. The companies in phase with the growing ecofriendly consumers started marketing green products, to showcase their attempt in preventing disposal of hazardous products into the human life and environment [2]. The factors such as Culture, Social aspects, personality traits, psychological state, economic aspect will influence the purchase behaviour of any customer [3]. Green marketing started driving the consumer demands to purchase green products thereby accelerates the environmental performance of products and services. 


\section{EVOLUTION OF GREEN MARKETING:}

Green Marketing started as a new business endeavour during the late 1980s and early 1990s [4]. American Marketing Association (AMA) in 1975 discussed 'Green Marketing' during the seminar or 'Ecological Marketing' and included in the literature for the first time. It emerged in Europe in the early 1980s as many products were found to be harmful to the society at large [5]. Two books with the identical name 'Green Marketing' was published in United Kingdom and United States of America written by Ken Pattie (1992) and Jacquelyn Ottman (1993) respectively. According to Peattie (2001) green marketing evolved in three phases. The first phase, focused on 'Ecological Marketing' to find solutions to the existing environmental problems. It introduced marketing practices to capture market and earn goodwill along with satisfying the consumers. This phase was not successful since all organisations started showcasing their products to be green just as a business trick but not in the real sense of green productivity and firms added environmental claims to their products for increasing the sale not for protecting the health of consumers or environment. In the second phase, 'Environmental' marketing was focused by giving importance to clean technology to design new products to prevent pollution and waste management. The Third phase emerged during late 1990s and early 2000 with 'Sustainable marketing' to develop good quality products meeting consumer needs through quality, performance, price and environment friendliness [6].

\section{GOING GREEN IN BUSINESS :}

In the course of locating different green consumers, the Research and Development wings of business realised that developed countries with two out of every three consumers and developing countries with one out of every six green consumers. The environmental commitment varies with standards, expectations of producers, demand and buying power of the consumers. Green Marketing determines to bring the activities of production, marketing, consumption and disposal of goods and services within the framework of going green to eliminate harms connected to global warming, non biodegradable solid wastes, pollutants etc. It involves efforts to generate sensitivity among marketers and consumers towards green products and services in business and consumption habits. Even though shifting to green business is expensive initially but with the growing consumerism, may be advantageous in near future [7]. It is a process of promotion of any product on the basis of it environmental performance to seek required improvements in that regard [8]. Green Marketing has attracted new set of customers who are conscious about environmental protection to prefer green products in their daily life [9]. It is also involved with managing the promotion activities to notify, presume and meet the demands of the consumers and society at large which intern gives profit and sustainability in business. The strategy to satisfy the stakeholders in business for maximum return, should not compromise human or environmental welfare [10]. Green consumers are those who prefer green products to carry out sustainable and socially responsible consumption practices. On the basis of changing consumer demands, the business organisations have segregated the market to satisfy each varied needs by using marketing mix strategy. The strategy adopted in green marketing should be measurable, sizeable, accessible, actionable, competitive intensity and growth potential [11]. According to Curlo (1999) in U.K 10 per cent consumers are hardcore green consumers [12]. Most of the consumers in the world have started to prefer green products and services as these will not harm the environment or destroy natural resources and flexible enough for recycling or conservation. Business started producing more green products and services not only with the environmental consciousness but due to the profitability involved in such business for effectively compete in the market. The following factors increased dependency over green products.

(a) Competitive Advantage: Growing green consumerism opened business opportunity to compete with those companies which are marketing products which are not environmentally sensitive. For instance, McDonald's changed clam shell packaging to waxed paper in accordance with consumer concern against polystyrene production and ozone depletion.

(b) Regulations: The policies are framed to protect the welfare of consumers and society at large by imposing government restrictions upon fixing standards on discharge of trade effluents, compelling waste management, limiting the production of harmful goods by prescribing quality standards, 
prohibiting consumption and distribution of hazardous goods, description about environmental composition over each goods etc. States have initiated performance auditing on water resources, control over pollution by the transport vehicles, standards on releasing toxic substances into the atmosphere etc.

(c) Competition: In order to maintain the competitive advantage over the competing business entities, industries have modified business practices by going green in terms of production, marketing, distribution, usage and aftermaths of production and consumption process. Firms adopted Value addition process and Management Systems in the firm level and Quality eco-friendly products in the product levels as strategies to go green.

(d) Social Responsibility: The business is a segment in the society which always should aim profit in the light of social betterment. The environmental issues are integrated into the corporate culture in order to tackle cost and profit aspects in business. Firms have started finding end solutions caused by the trade effluents to the environment by converting such waste itself to be the input for further production.

(e) Green Consumerism: People are gradually bringing greenness in to the life style by considering the aspects or health, quality and purity. The entrepreneurs started exploring environmental consciousness among the people as an opportunity for business. More production of green products has lead for Green Business revolution in India.

(f) Automation: Innovation and advancement in Technology is used as a weapon to produce more green products and promote green products into the competitive market with the essence of safe environment and sustainable development [13].

\section{GREEN INITIATIVES IN BUSINESS :}

The expanding population, fast urbanisation and hi-tech culture created opportunity for the development in India. The process of development created comfort to the people but affected the environment. For instance, the expansion of tourism has attracted human settlements in the tourist places but affected flora and fauna of that region. World Bank estimated that environmental damage in India amounts to 9.7 billion U.S. equal to 5 per cent of Gross Domestic Product. The leading companies like Wipro, Tata Consultancy Services, HCL, Haier, Samsung, Voltas, MRF Tyres etc. have adopted eco-friendly initiatives which improved profits in various ways [14]. The International Centre for Environment Audit and Sustainable Development was constituted at Jaipur for providing training about sustainable development. Green business is considered to be profitable with less cost, futuristic along with first mover advantages. HCL Technologies has developed a comprehensive Green Edge sustainability framework to meet the needs of manufacturing industries launching RoHS compliant laptop [15]. HCL received five star rating from the Bureau of Energy Efficiency for ecofriendly product and complied REACH an European Community Regulation on Chemicals and its safe use standard granted for the 100 per cent recyclable and toxic free products. In 2007, Voltas received Energy Star Ratings an International Standard for energy efficient consumer products originated in the US for using 20-30 \% less energy than the set standards. Panasonic is aiming to become top green innovation company in the electronics industry by 2018 emphasising on ecofriendly products. Nokia won Greenpeace Award which has launched a Nokia Bicycle Charger Kit (DC-14) which works at speed of $6 \mathrm{~km} / \mathrm{h}$ and stops charging at $50 \mathrm{~km} / \mathrm{h}$. Yes Bank is the first private Bank to sign United Nations Environment Protection Statement on Environment and Sustainable Development. Numerous business entities shown environmental consciousness through green initiatives in business to serve the consumer needs (Table 1).

Table 1: Green Initiatives by Key Business Entities in India

\begin{tabular}{|l|l|l|}
\hline \multicolumn{1}{|c|}{ Company } & \multicolumn{1}{|c|}{ Area } & \multicolumn{1}{c|}{ Green Initiatives } \\
\hline $\begin{array}{l}\text { State Bank of } \\
\text { India }\end{array}$ & Green IT & $\begin{array}{l}\text { 10,000 ATMs were constituted by using eco \& power } \\
\text { friendly equipments, Green Channel Counters, paper less } \\
\text { banking, ATM Cards }\end{array}$ \\
\hline $\begin{array}{l}\text { Kansai } \\
\text { Nerolac }\end{array}$ & $\begin{array}{l}\text { Social } \\
\text { Responsibility }\end{array}$ & $\begin{array}{l}\text { Lead free Products, Health, education, community } \\
\text { development and environment preservation. }\end{array}$ \\
\hline
\end{tabular}




\begin{tabular}{|c|c|c|}
\hline Wipro & Green IT & Reduction of carbon foot prints, environmental measures. \\
\hline $\begin{array}{l}\text { Wipro } \\
\text { Infotech }\end{array}$ & $\begin{array}{l}\text { Green } \\
\text { Machines }\end{array}$ & $\begin{array}{l}\text { Wipro Green ware desktops and laptops which reduce e- } \\
\text { waste. }\end{array}$ \\
\hline Tata Motors & $\begin{array}{l}\text { Econ Friendly } \\
\text { Showroom }\end{array}$ & Natural building, energy efficient lights. \\
\hline Taj Hotel & Eco Rooms & $\begin{array}{l}\text { Energy efficient mini bars, organic bed linen and napkins } \\
\text { made from recycled paper. }\end{array}$ \\
\hline $\begin{array}{l}\text { Indian } \\
\text { Railways }\end{array}$ & Digital Ticket & E-Tickets on their laptop and mobiles \\
\hline $\begin{array}{l}\text { HCL Info } \\
\text { Systems }\end{array}$ & Green IT & ISO 14001 Standards, Go green participation, RoHS Laptops \\
\hline LG India & $\begin{array}{l}\text { Eco-friendly } \\
\text { Products }\end{array}$ & $\begin{array}{l}\text { Eco-chic including platinum coated two door refrigerator and } \\
\text { washing machine with steam technology, } 40 \% \text { less energy } \\
\text { consumption, minimum usage of halogen or mercury. }\end{array}$ \\
\hline HCL & $\begin{array}{l}\text { Eco-friendly } \\
\text { Notebook }\end{array}$ & Poly Vinyl Chloride (PVC) and other harmful chemical free, \\
\hline $\begin{array}{l}\text { Samsung } \\
\text { Electronics }\end{array}$ & $\begin{array}{l}\text { Eco-friendly } \\
\text { features }\end{array}$ & $\begin{array}{l}\text { LED backlight without mercury or lead, } 40 \% \text { less energy } \\
\text { consumption, split ACs saving } 60 \% \text { energy. }\end{array}$ \\
\hline Voltas & Green Product & Air Conditioners with Energy star ratings \\
\hline $\begin{array}{l}\text { Panasonic } \\
\text { India }\end{array}$ & $\begin{array}{l}\text { Energy } \\
\text { Conservation }\end{array}$ & Home appliances using sensor and control technologies \\
\hline MRF Tyres & $\begin{array}{l}\text { Eco friendly } \\
\text { Product }\end{array}$ & $\begin{array}{l}\text { Tubeless Tyres made from unique silica based rubber } \\
\text { compounds for fuel efficiency }\end{array}$ \\
\hline ACC Ltd & $\begin{array}{l}\text { Conserve } \\
\text { Natural } \\
\text { Resources }\end{array}$ & ‘Concrete plus' manufactured out of fly ash (industrial waste) \\
\hline Grassroot & $\begin{array}{l}\text { Environmental } \\
\text { friendly brand }\end{array}$ & Eco friendly \& Organic fabrics \\
\hline $\begin{array}{l}\text { Vivanta by } \\
\text { Taj }\end{array}$ & Earth Friendly & $\begin{array}{l}\text { Follows United Nations Earth Summit endorsed by } 200 \\
\text { countries Monitored by Green Globe. }\end{array}$ \\
\hline Yes Bank & $\begin{array}{l}\text { Climatic } \\
\text { Change }\end{array}$ & $\begin{array}{l}\text { First Indian signatory to the carbon Disclosure Project by } \\
\text { documenting its Carbon Footprint. }\end{array}$ \\
\hline
\end{tabular}

\section{MERITS OF GREEN BUSINESS :}

Modern consumers prefer eco-friendly products and services, because of their environmental consciousness. The companies are trying to supply the products and services to meet consumer desires by ensuring protection of health and environment. Importance is given to non toxic products or neutral products along with availing early mover advantages offered by the government for green business. Some merits are listed as below [16].

(a) Cost: Companies engage in green practices like energy conservation to reduce energy consumption and cost of production by effective usage of solar energy. The green business involves less cost due to low production, maintenance and processing charges.

(b) Recycling: Green products are less harmful and prone to recycling. Organisations can reduce production cost by installing recycling units within the plants to reduce discharge quantity of wastage to the environment. Consumers started to check labels of products just to rectify whether packaging materials are recyclable.

(c) Tax Benefit: The liability of the employer to pay taxes to the government is reduced to those establishments which engage in green business. Government encourages employers to avail tax credits by producing and marketing eco friendly products and services.

(d) Morale: As the success of the organisation depends on the effective engagement of workforce. The energy efficient working environment will improve employee morale by reducing staff sick time by closely associating the employees in the task of health care and environmental protection with 
green activity.

(e) Public Relations: The positive efforts of companies to protect environment is viewed positively by the customers, suppliers and investors in the modern era. Green consumerism forced companies to build eco-friendly public image by protecting environment and health of the consumers.

(f) Consumer Satisfaction: As present consumers are eco-friendly, green features inculcated in the products and services definitely attract more and more consumers and bring consumer satisfaction.

(g) Less Environmental Impact: Green business keeps the environment safe by minimizing the hazard and eco hazard wastes arising out of production.

(h) Subsidies: Green business like energy efficient water heater will get assistance from State and Central Government in the form of purchase price rebates.

(i) Stability: Eco-friendly business integrates social and environmental components into business. These components improve performance of the business better than non green companies gaining profit.

(j) Cutting over heads: Green business reduces over head expenses involved in production, maintenance, quality assurance, stocking, marketing processes compared to non green products and services.

(k) Loyalty of Customers: The employer tries to uphold the goodwill of the company through green business acting according to the principles of integrity and best practices towards environmental protection will indirectly enrich loyalty of customers towards each product which are genuinely green.

\section{CHALLENGES IN GOING GREEN :}

The business entities are facing several challenges to start and maintain green business in India which is explained below.

(a) Lack of awareness: Green business is a new concept for enormous masses in the developing countries. People are not aware about varied green products and services. There is a need to educate the consumers about the harms caused by non green products to the health and environment.

(b) Cost: Going green from production to sale requires huge investment initially. Much money needs -to be used for research and development activities to produce and market green products, which increase cost price of the product.

(c) Higher Product Price: Green products are costlier than non green products. It is not easy to convince customers to purchase green products by paying higher premium price for the marketers. Generally green products are sold on the basis of additional product value present in the product.

(d) Reduction in profit: As the technology used for the production of green products are expensive, it is profitable in the long run. In case of green products, the long term business plan will only be profitable. Huge investments in innovations to carry green business will reduce the profit.

(e) Convincing the stakeholders: The Green business firms should try intensively to get the support of the stakeholders due to the long term profits involved in the business. Many stakeholders will not support green business entities due to the vagueness in accruing profit every year.

(f) Imbalance: Green products works as a bridge between environmental protection and customer satisfaction. Any misjudging or overemphasizing upon environmental protection or customer satisfaction at the cost of the other proves to be costly.

(g) Paper Free Transactions: Going green includes paper free business using information technology brings certain disadvantages. Information theft or piracy is proved to be disastrous.

(h) Customer Backlash: Companies put forth false propagandas about environment friendliness of certain products which is known to be green washing. If consumers recognise about false propagandas it will affect the good will of the company for the rest of its life.

\section{ANALYSIS AND DISCUSSION :}

This study analyse different Green Business Organisations listed in the Go Green Directory published by Eco-Deaz.com as on August, 2017. Table No-02 depicts about different categories of Green Business engaged in India. Total 471 organisations engage in 19 types of green business. About 89(19.00 per cent) in Alternative Energy, 63(13.00 per cent) Green Products, 48(10.00 per cent) Organic Food \& Drinks, Waste Management 39(08.00 per cent), Beauty \& Personal Care 34(07.00 
per cent), Organic Agriculture 34(07.00 per cent), Eco Fashion 23(05.00 per cent), Green Innovations 22(05.00 per cent), Art \& Craft 21(04.00 per cent), Green Architecture 19(04.00 per cent), Training \& Education 17(04.00 per cent), Water Conservation 15(03.00 per cent), Eco Tourism 15(03.00 per cent), Eco Friendly Packaging 12(03.00 per cent), Green Media 8(02.00 per cent), Rural Development 8(02.00 per cent), Herbal Medicine 2(01.00 per cent), Green Funding 2(01.00 per cent), Green Gadgets (Nil). It is inferred from the above analysis that Majority organisations are working in the area of Alternative energy, Green products, Organic food \& Drinks, Waste Management, Beauty \& personal care and organic agriculture. Less number of organisations is working in the areas of Green Media, Rural Development, Herbal medicine, Green funding. The companies working with the Green Gadgets have not registered under this directory so far.

Table 2: Types of Green Business in India

\begin{tabular}{|c|l|c|c|}
\hline Sl. No & \multicolumn{1}{|c|}{ Type of Business } & $\begin{array}{c}\text { No of } \\
\text { Organisations }\end{array}$ & Percentage \\
\hline $\mathbf{0 1}$ & Alternative Energy & 89 & 19.00 \\
\hline $\mathbf{0 2}$ & Green Products & 63 & 13.00 \\
\hline $\mathbf{0 3}$ & Organic Food \& Drinks & 48 & 10.00 \\
\hline $\mathbf{0 4}$ & Waste Management & 39 & 08.00 \\
\hline $\mathbf{0 5}$ & Beauty \& Personal Care & 34 & 07.00 \\
\hline $\mathbf{0 6}$ & Organic Agriculture & 34 & 07.00 \\
\hline $\mathbf{0 7}$ & Eco Fashion & 23 & 05.00 \\
\hline $\mathbf{0 8}$ & Green Innovations & 22 & 05.00 \\
\hline $\mathbf{0 9}$ & Art \& Craft & 21 & 04.00 \\
\hline $\mathbf{1 0}$ & Green Architecture & 19 & 04.00 \\
\hline $\mathbf{1 1}$ & Training \& Education & 17 & 04.00 \\
\hline $\mathbf{1 2}$ & Water Conservation & 15 & 03.00 \\
\hline $\mathbf{1 3}$ & Eco Tourism & 15 & 03.00 \\
\hline $\mathbf{1 4}$ & Eco Friendly Packaging & 12 & 03.00 \\
\hline $\mathbf{1 5}$ & Green Media & 08 & 02.00 \\
\hline $\mathbf{1 6}$ & Rural Development & 08 & 02.00 \\
\hline $\mathbf{1 7}$ & Herbal Medicine & 02 & 01.00 \\
\hline $\mathbf{1 8}$ & Green Funding & 02 & 01.00 \\
\hline $\mathbf{1 9}$ & Green Gadgets & 00 & 00.00 \\
\hline & Total & $\mathbf{4 7 1}$ & $\mathbf{1 0 0 . 0 0}$ \\
\hline
\end{tabular}

Source: www.ecodeaz.com

Eco-friendly Business in India:

Table 3: Eco-friendly Business Players in Karnataka

\begin{tabular}{|c|c|}
\hline Alternative Energy & Art \& Craft \\
\hline $\begin{array}{c}\text { Urja Solutions, Brihat Energy, Anu Solar } \\
\text { Power, Tata Power Solar Systems Ltd, } \\
\text { Arraytech Technologies Pvt Ltd, Chirantana } \\
\text { Green Technology Centre, Sustaiability Gift } \\
\text { Shoppe, Go Green Bov, Eagle Technologies, } \\
\text { EMMVEE Solar Systems Pvt Ltd, Kotak } \\
\text { Solar, Selco Solar }\end{array}$ & $\begin{array}{l}\text { Aa Totes Eco Friendly Bags, Aa Toes Eco } \\
\text { Friendly Designer Bags, Eco Save, PoKo Pets, } \\
\text { Craftizen Foundation, Kala Arts \& Crafts } \\
\text { Trust, Vasu Agarbathies, Shumeen } \\
\text { Manjari-Handmade Jewellery \& Handbags, } \\
\text { BG Handmade Speciality Papers }\end{array}$ \\
\hline Beauty \& Personal Care & Green Architecture \\
\hline $\begin{array}{l}\text { Amouve- Organic Bedding, Bubblenut Wash- } \\
\text { Natural Cleansing Products, Strategi-Herbal } \\
\text { Home Care Products, Schevaran Hill Green } \\
\text { Herbals Pvt Ltd, Ecobiased }\end{array}$ & $\begin{array}{l}\text { Green Leaf Arecawood Agro } \text { Enterprises, } \\
\text { Thermoshield India, Bamboooz: Innovative } \\
\text { Bamboo Furniture, Products \& Structures, } \\
\text { Esthete FAB Homes, Natura India Pvt } \\
\text { Ltd.,Centre for Green Building Material \& } \\
\text { Technology, En3 }\end{array}$ \\
\hline
\end{tabular}




\begin{tabular}{|c|c|}
\hline Eco Fashion & Eco friendly Packages \\
\hline Fessence, Sarga Eco Textiles & $\begin{array}{l}\text { Indigenous Innovations- Eco friendly bags, } \\
\text { Hone Core }\end{array}$ \\
\hline Eco Tourism & Green Funding \\
\hline Chukki Mane Nature Resorts & Arghyam \\
\hline Green Innovations & Green Product \\
\hline $\begin{array}{l}\text { Mahindra Reva Electric Vehicle Pvt Ltd, } \\
\text { Nualgi Nano Biotech, Aruna Green Ventures } \\
\text { Pvt Ltd., Solarity, Pradin Technologies, } \\
\text { HonECOre }\end{array}$ & $\begin{array}{l}\text { Green Path Organic State- Hasiru Thota, } \\
\text { Rajamane Telectric Products } \\
\text { Save Globe, Eco Essentials Areca Palm Plates, } \\
\text { AAF International, Inovex Enterprises Pvt } \\
\text { Ltd., Green Sense-Bio degradable Food Plates, } \\
\text { Shop for a Cause, Handcrafted Soaps by } \\
\text { SanGi, Eco Palm Leaf Plate Exporters, } \\
\text { Bhosale Bio Neem }\end{array}$ \\
\hline Organic Agriculture & Training \& Development \\
\hline $\begin{array}{l}\text { Centre for Agricultural Media (CAM), } \\
\text { Sanjivini Organic Manure \& Minerals, } \\
\text { ICCOA, Annadana Soil and Seed Savers, The } \\
\text { Organic Life, Agro Extracts Ltd., Barrix Agro } \\
\text { Sciences, Green Tech Life }\end{array}$ & $\begin{array}{l}\text { SayTrees, Institute for Cultural Research and } \\
\text { Action (ICRA), Soil \& Soul, Agabtya } \\
\text { International Foundation, Nispana Innovative } \\
\text { Platforms Pvt Ltd., BiBox, Ecole Solutions }\end{array}$ \\
\hline Waste Management & Organic Food \& Drinks \\
\hline $\begin{array}{l}\text { ReNewIT, Binbag, Green Nerds Solutions, I } \\
\text { Got Garbage, Encashea, E-Parisaraa Pvt. Ltd., } \\
\text { Pro Waste Concepts Pvt Ltd., SWMRT Solid } \\
\text { Waste Management round Table, Hasirudala, } \\
\text { Saahas }\end{array}$ & $\begin{array}{l}\text { Nature’s Fresh, Vegifresh Agro Exports, } \\
\text { Happy Jars Natural Peanut Butter, Kaulige } \\
\text { Foods, My Goat Goat Milk-Yashodavana Goat } \\
\text { Farm, Miracle Water, Lowkal, PURE } \\
\text { Products, Yogabar, Akshayakalpa Organic } \\
\text { Milk, Back2basics- Organic Vegetables \& } \\
\text { Food Products, Nectar Fresh, Herbal India } \\
\text { Products, Malnadkart.com, Honeyday-Food \& } \\
\text { Beverage Service \& Distributor, Vriksh-The } \\
\text { Organic Store, Green Theory-Vegetarian \& } \\
\text { Vegan Restaurant Cafe }\end{array}$ \\
\hline Water Conservation & Rural Development \\
\hline $\begin{array}{l}\text { Refurb-India } \text { Rainwater Harvesting, Amazon } \\
\text { Envirotech, } \quad \text { Refurb-India, Farmland } \\
\text { Rainwater Harvesting System (Rainy) }\end{array}$ & $\begin{array}{l}\text { BAIF Institute for Rural Development (BIRD- } \\
\text { K), Neralu, Eco-Agri Research Foundation }\end{array}$ \\
\hline Green Media & \\
\hline
\end{tabular}

Source: www.ecodeaz.com

Table 3 depicts about various Eco-friendly business players working in the state of Karnataka. Organisations are working in the areas of Alternative Energy, Art \& Crafts, Beauty \& Personal Care, Eco Fashion, Eco friendly packages, Eco Tourism, Green Architecture, Green Funding, Green Innovations, Green Media, Green Product, Organic Agriculture, Organic food \& drinks, Rural Development, Training \& Education, Waste Management, and Water Conservation.

\section{CONCLUSION :}

Consumers are considered to be kings in modern business. Meeting consumer needs is the main task of marketing. Indian customers are influenced by rapid technology, changing life style, online markets, varied products etc. Sustainable growth of business based on the consumer behaviour is a challenge. Making strategies to introduce green products to the customers shall be planned very well [17]. The Environmental problems are massively growing day by day. The process of development, growth in population and industrialisation has started impacting upon the environment, infrastructure 
and natural resources. The advancement in education, social media's and awareness consumers started preferring green products to control global warming by controlling pollution with eco friendly purchase and sale [18]. Green products have brought tremendous change in the business by inflicting aspects about pollution free life. Green consumerism encourages sustainable environment in spite of the changing lifestyles. People started preferring green products in spite of high price even changing their life style. Unless consumers change their behaviour firms alone cannot lead towards green business. The Government has enacted laws to protect natural resources such as water, forests and wild life of the country. Government, industries, companies and civil society are responding to handle the disequilibrium between economy and environment. The Ministry of Environment and Forest, Government of India on the basis of Environment Audit notification dated March $3^{\text {rd }}$, 1992 mandates submission of environmental statement to the Pollution control Boards. There is a need for separate disclosure of environmental liabilities. The aspects of green business, green army, green energy should be practiced with more vigour for sustainable development. Business organisations can effectively use world wide web, websites, emails, blogs, video chats, video conferencing, social medias to create awareness about any social cause [19]. Social work professionals can use different services empowered with technology like Email, Blogs, Video chat, Video Conferencing, Online Education, Social media, World Wide Web, Mobile phone and Websites in order to provide true support, improved quality of care to the needy. The industries should practice partnership instead of hegemony to maintain environmental safety. Emission standards for the vehicles are very much essential in the modern world. Green ambassadors shall be encouraged. Participatory process of energy conservation and environmental protection shall be practiced in every organisations. Every business must conduct SWOT analysis to review the impact of business upon the environment. The pros and cons of going green can be assessed by proper research and development activity. Aware consumers can compel organisations to integrate environmental concern into the corporate culture to minimise the detrimental effects upon the environment [20-27].

\section{REFERENCES :}

[1] Abdul Samad Shaikh \& Mustghis Ur Rahman (2011). Consumer Perception of Green Products: A Survey of Karachi. Journal of Independent Studies \& Research-(MSSE), 9(2), 15-23.

${ }^{2]}$ Jaya Tiwari. (2014) Green Marketing in India an Overview. ISOR Journal of Business and Management (IOSR- JBM), 1 (6), 33-40.

[3] Ramya N and S. A Mohamed Ali (2016). Factors affecting Consumer Buying Behavior. International Journal of Applied Research, 2(10), 76-80.

${ }^{[4]}$ Jacquelyn Ottman \& Virginia Terry (1998). Strategic Marketing of Greener Products. Journal of Sustainable Product Design, 5, 53-57.

[5] Yasmin Begum R.Nadaf \& Shamshuddin R.Nadaf (2014). Green Marketing: Challenges and Strategies for Indian Companies in $21^{\text {st }}$ century. IMPACT: International Journal of Research in Business Management (IMPACT: IJRBM), 2(5), 91-104.

[6] Peattie K (2001). Golden goose or wild goose? The hunt for the green consumer. Bus Stra Env, 10, 187-199. doi:10.1002/bse.292.

[7] Raghavendra, B. Ramesh, E. \& Rajesh, E. (2017). Green Marketing in India. $9^{\text {th }}$ International Conference on Recent Innovations in Science, Engineering and Management, Dhruva Insititute of Engineering and Technology, Nalgonda, Telangana, (RISEM-17), 28-29 $9^{\text {th }}$ January, ISBN: 978-93-86171-22-1.

[8] Charter M, Polonsky M.J. (1999). Greener Marketing: A Global Perspective on Greening Marketing Practice. Greenleaf Publishing.

[9] Pavan Mishra and Payal Sharma (2010). Green marketing in India: Emerging Opportunities and Challenges. Journal of Engineering, Science \& Management Education, 3, 9-16. 
[10] Anirban Sarkar (2012). Green Marketing and Sustainable Development-Challenges and Opportunities. International Journal of Marketing, Financial Services \& Management Research, 1(9), 120-134.

[11] Anirban Sarkar (2012). Green Marketing and Sustainable Development-Challenges and Opportunities. International Journal of Marketing, Financial Services \& Management Research, 1(9), 120-134.

[12] Mostafa, M. M. (2007). Gender differences in Egyptian Consumers, Green Purchase Behaviour: the effects of Environmental Knowledge, Concern and Attitude. International Journal of Consumer Studies, 31, 220-229,

[13] Synodinos, N. E. (1990). Environmental attitudes and knowledge: A Comparison of Marketing and Business Students with Other Groups. Journal of Business Research, 10(2), 161-170.

[14] Yasmin Begum R.N. and Shamshuddin R.N. (2014). Green Marketing: Challenges and Strategies for Indian Companies in $21^{\text {st }}$ Century" International Journal of Research in Business Management, 2(5), 91-104.

[15] Shamdasani, P, Chan-cin, G. O. and Richmond, D (1993). Exploring Green Consumers in an Oriental Culture: Role of Personal and Marketing Mix, Advances in Consumer Research, 20, 488-293.

[16] Pradeep, M.D. \& Akhilesh Suresh A Kuckian (2016). Green Marketing to meet consumer demands and sustainable development-Challenges and Opportunities. International journal of Advanced Trends in Engineering and Technology (IJATET), 1(1), 34-41.

${ }^{[17]}$ Deekshitha, M. A. Udaya Kumar \& M. D. Pradeep (2017). A Study on Changing Consumer Behaviour towards fast moving consumable goods in India. International Journal of Multidisciplinary Research and Modern Education, 3(1), 392-398.

[18] Geetha, D. Jenifer Annie (2014). A Study on Consumer Behaviour towards Purchase of Eco Friendly Products in Coimbatore. Abhinav International Monthly Refereed Journal of Research in Management \& Technology, 3(3), 1-8.

[19] Pradeep M. D. \& Krishna Prasad K (2016) “Modern Paradigm shift in Social Work Profession through Technology-New Dimension in Social Work Education" International Journal of Current Research and Modern Education (IJCRME), 1(1), 433-443.

[20] Pradeep M. D. \& Akhilesh Suresh A Kuckian (2016). Green Marketing to meet consumer demands and sustainable development-Challenges and Opportunities. International Journal of Advanced Trends in Engineering and Technology (IJATET), 1(1), 34-41.

[21] Aithal, P. S. \& Preethi J., (2016). How Service Industries can Transform themselves into Green Business Industries, International Journal of Management Sciences and Business Research (IJMSBR), 5(4), 150-158. DOI : http://doi.org/10.5281/zenodo.161114.

[22] Prithi Rao, and Aithal, P.S. (2016). Green Education Concepts \& Strategies in Higher Education Model. International Journal of Scientific Research and Modern Education (IJSRME), 1(1), 793802. DOI : http://doi.org/10.5281/zenodo.160877.

[23] Sridhar Acharya P. \& Aithal, P. S. (2016). Impact of Green Energy on Global Warming - A Changing Scenario, International Journal of Scientific Research and Modern Education (IJSRME), 1(1), 838-842. DOI : http://doi.org/10.5281/zenodo.154575.

[24] Aithal, P. S. and Shubhrajyotsna Aithal, (2016). Opportunities \& Challenges for Green Technology in $21^{\text {st }}$ Century. International Journal of Current Research and Modern Education (IJCRME), 1(1), 818-828. DOI : http://doi.org/10.5281/zenodo.62020. 
[25] Varun Shenoy, and Aithal, P. S. (2016). Green Placement - An Innovative Concept \& Strategy in Campus Placement Model. IRA- International Journal of Technology \& Engineering, 4(3), 151163. DOI : http://dx.doi.org/10.21013/jte.v4.n3.p3.

[26] Sridhar Acharya, P. \& Aithal, P.S. (2015). Innovations in Effective Management of Energy using Green Technology, International Journal of Conceptions on Management and Social Sciences, 3(2), 18 - 22. DOI : http://doi.org/10.5281/zenodo.268814.

[27] Aithal, P. S. and Jeevan, Priti, (2016). Strategic Rethinking of Management Education: Green MBA Model. International Journal of Management, IT and Engineering, 6(1), 55-73. DOI : http://doi.org/10.5281/zenodo.154278. 